\title{
The Cost of Misguided Urbanization: The Case of Informal Settlements in Butuan City, Philippines
}

\author{
Ma. Kresna D. Navarro, MA \\ Economics Department, Xavier University-Ateneo de Cagayan \\ Email: mnavarro@xu.edu.ph

\section{Catherine Roween C. Almaden, MA} \\ College of Arts and Sciences, Xavier University-Ateneo de Cagayan \\ Email: calmaden@xu.edu.ph
}

Doi:10.5901/ajis.2014.v3n6p441

\begin{abstract}
The informal settlements in Butuan City, Philippines pose the intractable problem of housing and providing services for the urban poor. They exact tremendous costs to government infrastructure projects and the city as a whole. In this study, these costs are accounted for, particularly the costs the government will incur to compensate them for being displaced in the implementation of public infrastructure project. Primary data were collected through inventory of losses (IOL), socio-economic survey (SES) and the replacement cost surveys. Secondary data were obtained through key informant interviews with different stakeholders. The paper quantifies the costs of compensating them thru replacement of their affected resources and providing resettlement. It also establishes different types of compensation to secure just terms for all parties. It presents a rich picture of how the informal settlers affect urban environment and the monetary and operational challenges they pose to the government and the society at large.
\end{abstract}

Keywords: Informal Settlements, Social Cost, Urbanization

\section{Introduction}

\subsection{Background of the Study}

The occurrence of flooding in Butuan City, Philippines exacts a heavy toll in terms of economic and physical losses. To respond to this problem, a drainage improvement project was implemented to reduce the incidence of flooding within the city. This project was covered by the Butuan City Drainage Improvement Project (BCDIP) Phase 1, a sub-project of Agusan River Basin Integrated Water Resources Management Program (ARBIWRMP).

However, the intervention resulted in some involuntary displacement of 175 informal settlers as potentially affected households (PAHs). Against this backdrop, the study focuses on accounting for the social cost of compensating them justly for being displaced due to the proposed flood mitigation project of Butuan City.

\subsection{Objectives of the Study}

This study aimed to conduct estimation of the costs the government will incur in compensating the informal settlers affected by the Butuan City Drainage Improvement Project Phase 1. The paper poses two specific research questions: first, describing the modalities for compensating the informal sectors, including the existing legislative, and policy framework of informal settlement. Second, accounting for the estimated cost the modalities will incur to the local government. 


\section{Review of Related Literature}

\subsection{Informal Settlements as an Urbanization Problem}

The myopic and unguided economizing plan of the government without proper land use planning, effective infrastructure development or social housing program for informal resettlement due to expanding in-migration may resolve short term problem but eventually result to greater social costs (Rojas \& Magalhaes, 2010; Ferguson, 1996). Nonetheless, informal settlements have become persistent feature of urbanization and globalization (Tsenkova et al., 2008).

Literatures enumerated six characteristics of informal settlements for which create environmental and urban development problems (Ferguson, 1996; Rojas \& Magalhaes, 2004). First, informal settlers squat on areas typically lack a road network. Second, these dwellers settle in a denser are with poor or no adequate public facilities which increase their vulnerability to diseases and criminalities. Third, quality of electricity is often below formal sector standards are common sight in these communities. Fourth, access to quality drinking water increases the susceptibility to waterborne diseases and poor sanitation. Fifth, poor sanitation and waste water discharged experience by households in informal sector are largely attributed from the enumerated characteristics of dwelling enumerated above. Sixth, unplanned settlement generates water pollution and wastes accumulation as raw sewerage and garbage are thrown directly to nearby water system and open spaces (Rojas \& Magalhaes, 2004. Table below summarizes of the major types of informal settlements with a reference to their location and quality.

Table 1. Matrix of Informal Settlement Types

\begin{tabular}{|l|c|c|c|c|}
\hline \multirow{2}{*}{ Informal Settlement Types } & \multicolumn{3}{|c|}{ Location } \\
\cline { 2 - 5 } & $\begin{array}{c}\text { Inner } \\
\text { City }\end{array}$ & $\begin{array}{c}\text { Peri- } \\
\text { urban }\end{array}$ & Substandard/Slums & $\begin{array}{c}\text { Relatively good } \\
\text { quality }\end{array}$ \\
\hline Squatter settlements on public or private land & $\mathrm{X}$ & $\mathrm{X}$ & $\mathrm{X}$ & \\
\hline Settlements for refugees and vulnerable people & $\mathrm{x}$ & & $\mathrm{X}$ & \\
\hline Upgraded squatter settlements & $\mathrm{x}$ & $\mathrm{x}$ & & $\mathrm{X}$ \\
\hline Illegal suburban land subdivisions on private or public land & & $\mathrm{x}$ & & $\mathrm{X}$ \\
\hline Overcrowded dilapidated housing without adequate facilities & $\mathrm{x}$ & & $\mathrm{X}$ & \\
\hline
\end{tabular}

Source: Tsenkova et al., 2008

Tsenkova et al. (2008) posted three costs of informal settlement, namely: economic, social and environmental. Informal settlements siphon considerable public and private investment outside the formal economy and investment cycle (De Soto, 2003). Notwithstanding the economic challenges faced by the individual occupant, informal settlements pose a high political and economic cost for the government and the public in cases of evictions, legalization and resettlements.

\subsection{Upgrading of Informal Settlements}

Recognizing the economic, social and environmental challenges of informal settlements is an important step toward practical and well-thought out urban housing policies. Providing security of tenure for informal settlers has been an integral part of most upgrading projects implemented in the last thirty years. Numerous evidences suggest that, a welladministered slum upgrading, has significant linkages with the socio-economic well-being of the poor in every society. It can help in combating poverty and vulnerability, achieving sustainable human development, and promoting environmental sustainability (UN Habitat Working Paper 2003; Global Report on Human Settlement Revised, 2010).

Rather than strive to eliminate informal settlements, governments began to formulate ways to accommodate existing informal settlements and to capitalize upon the energies that built the settlements in the first place. Under this new policy direction, governments withdrew from directly producing housing units and instead focused on enabling or facilitating settlement improvement by ensuring the availability of the basic inputs, namely urban infrastructure, land with tenure security, and appropriate financial and technical services, that enable people to improve their living situation themselves (Keare and Parris, 1982).

The provision of improved infrastructure and services to informal settlements is another central component of upgrading and one with the greatest record of success. This includes provision of basic infrastructure services such as water, sanitary facilities, roads, and street lighting, in a manner that is affordable to the urban poor. Many projects have 
resulted to better living standards and health indicators (Cohen, 2001).

Upgrading resettlement projects should also generate additional income for the urban poor. Studies conducted in India, the Philippines, and Brazil have shown that slum upgrading programs have a positive impact upon income by facilitating the establishment or expansion of home-based enterprises (HBEs) (Mehta and Mehta 1990).

A final solution is to relocate or resettle informal settlers. Relocation is intra-settlement in nature, basically shifting residents to new locations within their original neighborhood. Relocation is commonly caused by installation of infrastructure, such as opening up new roads or installing water pipes or sewerage. As expected, the degree of relocation within a settlement is linked to standards and has implications for project costs. Higher standards for parcel sizes, road reserves and infrastructure will cause more dislocation. Resettlement can be thought of as extra-settlement in nature: squatters are moved to a completely new place. In resettlement, projects must do more than move people; they must provide physical infrastructure as well as economic opportunities and social services (World Bank, 2003).

\section{Methodology}

Primary data were collected through inventory of losses (IOL), socio-economic survey (SES) and the replacement cost surveys. Implementation of these surveys took place in January to early March 2011. The census and IOL covered 100\% of project-affected persons. The SES took a sample of $20 \%$ of severely affected households which have more than $10 \%$ of their productive assets to be affected by the project and $10 \%$ of all other PAHs. The replacement cost survey obtained data on the value of affected assets and the cost of replacing them as a basis for compensation.

In addition, Key Informant Interviews were also conducted to various government officials of key government agencies to generate the needed information on current market replacement and resettlement costs.

Lastly, the researchers also gathered primary information through scheduled visits to the city and site observations which involved recording of the various resources found in the communities, nature of housing, household/business activities, and potential attributes for community development. Table 2 presents the complete list of methodology and sources of information

Table 2. Methodology and Sources of information

\begin{tabular}{|c|c|c|}
\hline \multirow{2}{*}{$\begin{array}{l}\text { Needed/Required } \\
\text { Information/Data }\end{array}$} & \multicolumn{2}{|c|}{ Methodology } \\
\hline & Primary Sources & Secondary Sources \\
\hline List of Affected Barangays & \multirow{4}{*}{$\begin{array}{l}\text { Interviews with Affected and Unaffected } \\
\text { Households/Businesses }\end{array}$} & City Housing Office \\
\hline $\begin{array}{l}\text { Market Prices for Lot/Barangay } \\
\text { per square meters }\end{array}$ & & $\begin{array}{l}\text { City Assessor Office and five (5) } \\
\text { Commercial Banks } \\
\text { DPWH }\end{array}$ \\
\hline Market Prices for Structures & & City Assessor Office \\
\hline $\begin{array}{l}\text { Market Prices for Crops and } \\
\text { Trees }\end{array}$ & & City Agriculture and City Assessor Office \\
\hline Prices of Construction Materials & \multirow{3}{*}{$\begin{array}{l}\text { a) Interviews with eight (8) affected and (8) } \\
\text { unaffected household and businesses } \\
\text { b) Key Informant Interview includes: three (3) owner } \\
\text { of construction company; three (3) land developers; } \\
\text { and three (6) hardware store owners }\end{array}$} & \multirow{3}{*}{$\begin{array}{l}\text { City Housing Office } \\
\text { DPWH }\end{array}$} \\
\hline Labor Cost & & \\
\hline Average Construction Cost & & \\
\hline
\end{tabular}

The secondary data were sourced from various government agencies. The list of affected barangays was provided by the City Housing Office. The data on comparative market prices for structures and lot per barangay were gathered from the City Assessor's Office, National Housing Authority (NHA) and the Department of Public Works and Highways (DPWH). Information for the market prices for perennial plants was obtained from the City Agriculture Office.

A standardized questionnaire was utilized for interviews with households and businesses, in affected areas. An interview guide was used for the key informant interviews which include information regarding current reproduction costs of structures and most common materials used in construction by local people. 


\section{Results and Discussion}

\subsection{Housing Needs in Butuan City}

This high incidence of informal settlements can be attributed to the shortage of low cost housing in Butuan City. In 20092010, the Statistical Research and Training Center (SRTC), as the research and training arm of the Philippine Statistical System (PSS), in collaboration with Housing and Urban Development and Coordinating Council (HUDCC), conducted a research entitled "Housing Backlog Study" under the "Development of Shelter Monitoring Information System (DSMIS) Project."

Table 3. Housing Needs Estimates by Housing Indicator in CARAGA Region and Butuan City, May 2010

\begin{tabular}{|c|c|c|c|c|c|c|}
\hline \multirow{2}{*}{ Location } & \multicolumn{6}{|c|}{ Accumulated Needs } \\
\cline { 2 - 7 } & $\begin{array}{c}\text { Rent-free without } \\
\text { consent of owners }\end{array}$ & $\begin{array}{c}\text { Homeless } \\
\text { (Other type of } \\
\text { Housing Units ) }\end{array}$ & $\begin{array}{c}\text { Dilapidated/ } \\
\text { Condemned }\end{array}$ & $\begin{array}{c}\text { Marginal } \\
\text { Housing }\end{array}$ & $\begin{array}{c}\text { Doubled-up Households in } \\
\text { Acceptable Housing Units }\end{array}$ & Total \\
\hline CARAGA Region & 12,637 & 28 & 3,439 & 4,196 & 8,900 & 29,200 \\
\hline Butuan City & 2,645 & 3 & 451 & 269 & 1,243 & 4,611 \\
\hline
\end{tabular}

Source: National Statistics Office

Following table 3 shows the Housing Needs (accumulated needs) estimates as of May 1, 2010 with CARAGA regional breakdown as well as for Butuan City. This shows that as of that point in time, total accumulated housing needs is at 12,637 and 2,645, respectively.

Another component of the research project with HUDCC is the identification of Informal Settler Families (ISFs). The SRTC, in collaboration with the Technical Working Group on Housing Statistics of the Technical Committee on Population and Housing Statistics coordinated by National Statistics Coordination Board, proposed for its operational definition:

Informal settlers are individuals/households living under any of the following conditions: lot without consent of the property owner (informal settler); danger areas (along riverbanks, railways, under the bridge, etc); areas for government infrastructure projects; protected/forest areas (except for indigenous peoples); Areas for Priority Developments (APDs); other government/public lands or facilities not intended for human habitation.

Households under the status "rent-free without consent from owners" or informal settlers comprise $58 \%$ at the regional level and $85 \%$ in Butuan City of the total need for housing. From the survey results, this prevalence, as well as the increase in the number of informal settlers in the city, is due to natural increases as well as in-migration. An estimated 90 per cent of the residents lack steady jobs and usually work as hired laborers on an irregular basis, peddlers, load carriers, household help, construction workers, among others. The relative low growth rate of the business sector has accentuated the city's problem of inadequate labour absorption.

Table 4. Number of Households and Informal Settlers in CARAGA Region and Butuan City: 2000, 2010

\begin{tabular}{|c|c|c|c|c|c|c|c|c|}
\hline \multirow{2}{*}{ Location } & \multicolumn{4}{|c|}{2000} & \multicolumn{4}{c|}{2010} \\
\cline { 2 - 9 } & $\begin{array}{c}\text { Number of } \\
\text { Households }\end{array}$ & $\begin{array}{c}\text { Rent-free } \\
\text { without } \\
\text { consent of } \\
\text { owners }\end{array}$ & $\begin{array}{c}\text { Incidence } \\
\text { (Percent) }\end{array}$ & $\begin{array}{c}\text { Ranked } \\
\text { Incidence }\end{array}$ & $\begin{array}{c}\text { Number of } \\
\text { Households }\end{array}$ & $\begin{array}{c}\text { Rent-free } \\
\text { without } \\
\text { consent of } \\
\text { owners }\end{array}$ & $\begin{array}{c}\text { Incidence } \\
\text { (Percent) }\end{array}$ & $\begin{array}{c}\text { Ranked } \\
\text { Incidence }\end{array}$ \\
\hline CARAGA Region & 386,283 & 16,978 & 4.4 & $\begin{array}{c}\text { No 2 } \\
\text { (out of 17) }\end{array}$ & 504,257 & 12,637 & 2.51 & $\begin{array}{c}\text { No 4 } \\
\text { (out of 17) }\end{array}$ \\
\hline Butuan City & 50,273 & 3,927 & 7.81 & $\begin{array}{c}\text { No 6 } \\
\text { (out of 18) }\end{array}$ & 65,642 & 2,645 & 4.03 & No 11 (out of 18) \\
\hline
\end{tabular}

Source: National Statistics Office 


\subsection{Modalities of Compensating the Informal Settlers as Project Affected Households}

\subsubsection{Provision of Replacement Cost under the Premise of Fair Market Value and Subjective Value}

Most countries around the world have constitutional and/or statutory standards that call for Fair Market Value (FMV) compensation for lost assets that the state expropriates. A second approach calls for Replacement Cost (RC). The compensation at Fair Market Value and Replacement Cost is dependent on (i) markets provide reliable information about prices and (ii) comparable assets or acceptable substitutes are available for purchase. The FMV is commonly defined as the amount that the land and structure might be expected to realize if sold in the open market by a willing seller to a willing buyer (Knetsch and Borcherding, 1979).

Most governments in high- and middle-income countries with well-functioning legal systems have adopted FMV of the appropriated asset as the standard for determining compensation for state expropriations. The underlying reason for adopting the fair market value standard is that the market is an objective gauge for assessing the value of the land. Under the FMV standard, land expropriation laws in many of these countries provide further practical rules to guide adherence to the standard. Some countries provide a premium above the FMV because of the involuntary nature of the taking. In a compulsory land taking, the government is a willing buyer, but the affected landowners are often not willing sellers. Some governments have developed a variety of mechanisms to compensate landowners in excess of market value because of the involuntary nature of the taking (Ackerman, 1994).

In this study, FMV is based on the perspective of the City Assessor's and the private entities represented by banks and construction companies/developers.

On the other hand, RC for structures is computed in terms of the fair market value (direct costs which include materials, labor, developer's fee, etc.) plus indirect costs that include monetary cost of obtaining a building permit, fire protection permit, and real estate taxes.

In the Philippines, the indirect costs for structures involve building permit plus fire protection fee and insurance: USD199.89 (strong materials) and USD99.94 (light materials), real estate tax for residential properties equivalent to $1 \%$ of the zonal value or fair market value, whichever is higher; and for commercial properties equivalent to $1.75 \%$ of the zonal value or fair market value, whichever is higher. This is based on year 2010 value, $1 \$$ is to PhP40.023.

A third approach used in this study is the Subjective Value. Subjective value is the amount of money or money's worth in return for which the owner would willingly part with a piece of property, whether or not there exist a willing purchaser at such a price. This is also referred to as reserve price. This is under the assumption that owners of all existing properties would have established in their minds a subjective value for their properties based upon their evaluation of the future returns to them personally. Such personal returns from the amenities enjoyed in their individual properties would be in excess of the demand prices of buyers in the market as evidenced by the fact that only a very small fraction of all properties are even offered for sale.

\subsubsection{Compensations Rates for Structures Adopted in the Study}

From existing practice of City Housing Office and from other secondary sources, the research adopted an 8-typology of structures which apply to both housing and business establishments. The typologies are as follows with corresponding descriptions (see Table 5). Predominance is attributed to the material used more than $50 \%$ of the structure (ie roof or wall). For most informal settlers, their houses are mixed but predominantly strong, makeshift; and mixed but predominantly makeshift.

Table 5. Eight Typologies of Structures

\begin{tabular}{|l|l|l|}
\hline \multicolumn{2}{|l|}{ Typologies } & Description \\
\hline A & Strong & $\begin{array}{l}\text { Galvanized Iron sheets; hardwood/ concrete foundation, columns, beam, walls and } \\
\text { flooring; complete finishing and tilings. }\end{array}$ \\
\hline B & Light & $\begin{array}{l}\text { Nipa for roofing; lumber/bamboo for foundation, columns, beams and flooring; and } \\
\text { amakan/light plywood for walls }\end{array}$ \\
\hline C & $\begin{array}{l}\text { Mixed but predominantly } \\
\text { strong }\end{array}$ & More than fifty percent of the structure is made up of strong materials. \\
\hline D & Mixed but predominantly light & More than fifty percent of the structure is made up of light materials. \\
\hline E & Makeshift & Made up of salvaged materials \\
\hline
\end{tabular}




\begin{tabular}{|l|l|l|}
\hline F & $\begin{array}{l}\text { Mixed but predominantly } \\
\text { makeshift }\end{array}$ & $\begin{array}{l}\text { Made up of different construction materials but more than fifty percent is made up of } \\
\text { makeshift materials }\end{array}$ \\
\hline G & $\begin{array}{l}\text { Semi finished but } \\
\text { predominantly strong }\end{array}$ & Partially finished structure using predominantly strong materials. \\
\hline H & $\begin{array}{l}\text { Semi finished but } \\
\text { predominantly light }\end{array}$ & Partially finished structure using predominantly light materials. \\
\hline
\end{tabular}

Table $7 \& 8$ shows the market valuations of the different typologies of affected structures and commercial buildings in the areas. The values presented in Table 6 are based on current market values and developer's cost. The current market values were obtained from the City Assessor's Office. The developer's cost is based on the highest cost set from the three developers per typology.

Table 6. Reproduction Cost for Three Developers

\begin{tabular}{|l|c|c|c|}
\hline \multirow{2}{*}{ Typology } & \multicolumn{2}{|c|}{ Cost per Square Meters (PhP) } \\
\cline { 2 - 4 } & $\begin{array}{c}\text { Jec's } \\
\text { Construction }\end{array}$ & $\begin{array}{c}\text { Kryzel's } \\
\text { Construction }\end{array}$ & $\begin{array}{c}\text { Engr. Buenaflor's } \\
\text { Construction }\end{array}$ \\
\hline Strong Materials & 25,000 & 7,500 & 19,000 \\
\hline Light Materials & 8,000 & 7,000 & 15,000 \\
\hline Mixed but predominantly strong materials & 12,000 & 6,000 & 17,000 \\
\hline Mixed but predominantly light materials & 10,000 & 5,500 & 13,000 \\
\hline Salvaged/Make-shift materials & 1,000 & 3,000 & 5,000 \\
\hline Mixed but predominantly salvaged materials & 6,000 & 4,500 & 7,000 \\
\hline Semi finished but predominantly strong materials & 14,000 & 6,500 & 15,000 \\
\hline Semi finished but predominantly light materials & 7,000 & 5,000 & 10,000 \\
\hline
\end{tabular}

Table 7: Household Structure Rate per Typology

\begin{tabular}{|l|c|c|c|c|}
\hline \multirow{2}{*}{ Types of Residential Structure } & \multirow{2}{*}{$\begin{array}{c}\text { Commercial } \\
\text { Developer's } \\
\text { Perspective (sqm) }\end{array}$} & \multicolumn{2}{|c|}{ City Assessor's Office (sqm) } & $\begin{array}{c}\text { Respondent's Perspective } \\
\text { (sqm) } \\
\text { *Subjective valuation }\end{array}$ \\
\cline { 3 - 5 } & USD 424.76 & Residential & ^Animal Coop & Affected Households \\
\hline Mixed but predominantly strong materials & USD -USD 112.94 & USD 49.97-USD 52.72 & USD 62.46 \\
\hline Salvaged/Make-shift materials & USD 124.93 & USD 46.47-USD 48.22 & & USD 12.49 \\
\hline Mixed but predominantly salvaged materials & USD 174.90 & USD 51.72-USD 54.22 & & USD 16.24 \\
\hline
\end{tabular}

At 2010, 1\$: PhP40.023

^Animal Coop: PigPen/Hog house, Poultry and Goat House

Table 8: ^Commercial Structure Market Value per Typology

\begin{tabular}{|l|c|c|c|}
\hline Type of Commercial Structure & $\begin{array}{c}\text { Commercial Developer's } \\
\text { Perspective (sqm) }\end{array}$ & $\begin{array}{c}\text { City Assessor's Office } \\
\text { (sqm) }\end{array}$ & $\begin{array}{c}\text { Respondent's Perspective (sqm) } \\
\text { * Subjective valuation }\end{array}$ \\
\hline Mixed but predominantly strong materials & USD 424.76 & USD 107.44 - USD 113.18 & USD 107.06 \\
\hline Salvaged/Make-shift materials & USD 124.93 & USD 46.47 - USD 48.72 & USD 14.99 \\
\hline Mixed but predominantly salvaged materials & USD 174.90 & USD 51.47 - USD 54.22 & USD 18.74 \\
\hline
\end{tabular}

At 2010, 1\$: PhP40.023

^Commercial Building includes apartment stores, restaurant, carenderia/eatery, sari-sari stores, dress/tailoring shops, KTV bar and hard wares

\subsubsection{Valuation of Non-tenured Properties}

In the case of Butuan City, the areas that were affected by the project predominantly consist of informal settlers. As a result some of the households and businesses interviewed were uncomfortable disclosing their valuation of the land and structure valuation because the nature of their settlement. They know that anytime the lots will be used, their structures will be demolished.

In the Philippines, the policy framework limits resettlement options to those whose tenure is insecure. Also, if the place of business is the pedestrian walkway, other easements, or the road itself, the law declares that these places are 
"beyond the commerce of man" and, therefore, they have no right to build or conduct business there in the first place. Their structures are illegal and therefore not subject to compensation when dismantled. Neither does the law provide any compensation for their loss of income during relocation.

\subsubsection{Estimated Replacement Costs for Structures of Project Affected Household}

The Replacement Cost (RC) approach for structures in a typical developed country setting of active markets is based on the theory that the market value of an improved parcel can be estimated as the sum of the land value and the depreciated value of the improvements. In other words, subtracting the land value from the overall value of the house and land will get the value of the house. Its underlying principle is that an informed buyer will pay no more for an improved property than the price of acquiring a vacant site and constructing a substitute building of equal utility, (Eckert, 1994).

The RC approach requires descriptive data on the improvements being valued. It is also important to determine an accurate cost estimate. Costs consist of all expenditures necessary to complete construction of a house or other building. They are either direct or indirect costs. Direct costs include materials and labor, while indirect costs include monetary cost of obtaining a building permit, registering the house with relevant government agency, insurance and real estate taxes.

For mass appraisal, the comparative unit method is widely used. This method, constructed based on the unit-inplace method, simplifies the estimation process by grouping all itemized direct costs and indirect costs into a composite unit cost expressed in square foot of ground area or floor area or cubic feet of space. The unit cost further breaks down based on quality of the structure and the number of stories. Percentage or lump-sum adjustments for features not included in comparative unit cost may be made with the unit-in place method. Cost estimations for both single-property appraisals and for mass appraisals attempt to answer the question, "How much does it cost to build the same structure today?" In this study, this achieved though the cost estimates provided by the real estate developers reflected in Table 9. Building cost data are readily available for valuation purposes which fit well with this approach. In the Philippine, the government does not account transaction costs for buildings made of salvaged and mixed but predominantly salvaged materials. Businesses and households living in these construction materials are informal settlers in the area.

The last step for valuing structures is to estimate accrued depreciation. Accrued depreciation is the loss in value from replacement cost which is defined as the replacement cost as if the similar structure were built as of the date of appraisal. This depreciation is based on the concepts of the structure economic age and economic life. The concept here is that, as the structure ages in time, its physical value will diminished. For the case of informal settlers, the cost of building their structure is purely direct cost because construction of their structures did not go into legal means hence, they did not paid for any indirect costs like building permit, fire protection fee, insurance and real estate tax.

Table 9. Commercial Developer's Cost and Economic Valuation

\begin{tabular}{|c|c|c|c|c|c|c|}
\hline \multirow{3}{*}{ Types of Structure } & \multirow{3}{*}{$\begin{array}{c}\text { Commercial } \\
\text { Developer's Cost } \\
\text { (psm) }\end{array}$} & \multicolumn{5}{|c|}{ Economic Valuation } \\
\hline & & \multicolumn{2}{|c|}{$\begin{array}{l}\text { Direct and Indirect } \\
\text { Costs }\end{array}$} & \multirow{2}{*}{$\begin{array}{c}\text { Life Span in } \\
\text { years }\end{array}$} & \multicolumn{2}{|c|}{$\begin{array}{c}\begin{array}{c}\text { Depreciation Cost per } \\
\text { Year }\end{array} \\
\end{array}$} \\
\hline & & Residential & Businesses & & Residential & Businesses \\
\hline Mixed but predominantly strong materials & USD 424.76 & USD112.94 & USD113.18 & 18 & USD29.87 & USD29.89 \\
\hline Salvaged/Make-shift materials & USD 124.93 & USD 48.22 & USD 48.72 & .5 & USD 0 & 0 \\
\hline Mixed but predominantly salvaged materials & USD 174.90 & USD 54.22 & USD 54.22 & 1.5 & USD152.76 & USD152.76 \\
\hline
\end{tabular}
At 2010, 1\$: PhP40.023

Table 10 below displays the market value, respondent's perspective, and replacement cost for the structure per typology. Replacement Costs are based on the interplay of commercial developers' cost and depreciation cost. Depreciation cost is computed for one year only. Therefore, the recommended rate of the structure is computed for one year depreciation cost. Replacement cost is derived by deducting one year depreciation cost to commercial developer's cost. As shown in the Table 9, structure made of salvaged materials has a life span of six months, while structure made of mixed but predominantly salvaged materials has a life span of eighteen months. The replacement costs for structures on mixed but predominantly strong materials, salvaged and mixed but predominantly salvaged materials exclude the cost for building permit, fire protection permit, insurance fee and real estate tax. Aside from that, replacement cost of structures made of salvaged materials is zero due to its shorter life span. This structure is fully depreciated before one year. Structures made of these materials are used by informal settlers in the area without any user costs for the construction of the building. 
Table 10. Market Value and Replacement Costs for Structure

\begin{tabular}{|c|c|c|c|c|c|c|c|}
\hline \multirow[b]{2}{*}{ Types of Structure } & \multirow[b]{2}{*}{$\begin{array}{c}\text { Commercial } \\
\text { Developer's } \\
\text { Perspective (sqm) }\end{array}$} & \multicolumn{2}{|c|}{$\begin{array}{l}\text { Residential } \\
\text { (sqm) }\end{array}$} & \multicolumn{2}{|c|}{$\begin{array}{l}{ }^{\wedge} \text { Commercial } \\
\text { (sqm) }\end{array}$} & \multicolumn{2}{|c|}{$\begin{array}{l}\text { Replacement Cost } \\
\text { (sqm) }\end{array}$} \\
\hline & & $\begin{array}{l}\text { City Assessor's } \\
\text { Market Value }\end{array}$ & $\begin{array}{l}\text { Respondent's } \\
\text { Perspective } \\
\text { *subjective } \\
\text { valuation }\end{array}$ & $\begin{array}{l}\text { City Assessor's } \\
\text { Market Value }\end{array}$ & $\begin{array}{l}\text { Business } \\
\text { Perspective } \\
\text { *subjective } \\
\text { valuation }\end{array}$ & $\begin{array}{c}\text { Househol } \\
\text { d }\end{array}$ & Business \\
\hline $\begin{array}{l}\text { Mixed but predominantly strong } \\
\text { materials }\end{array}$ & 424.76 & $\begin{array}{l}\text { USD 107.6- } \\
\text { USD 112.94 }\end{array}$ & USD 62.46 & $\begin{array}{l}\text { USD } 107.44- \\
\text { USD } 113.18\end{array}$ & USD 107.06 & $\begin{array}{c}\text { USD } \\
394.89\end{array}$ & $\begin{array}{c}\text { USD } \\
394.87\end{array}$ \\
\hline ^Salvaged/Make-shift materials & 124.93 & $\begin{array}{l}\text { USD 46.47- } \\
\text { USD } 48.22\end{array}$ & USD 12.49 & $\begin{array}{l}\text { USD } 46.47- \\
\text { USD } 48.72\end{array}$ & USD 14.99 & 0 & 0 \\
\hline $\begin{array}{l}\text { Mixed but predominantly salvaged } \\
\text { materials }\end{array}$ & 174.90 & $\begin{array}{l}\text { USD } 51.72- \\
\text { USD } 54.22\end{array}$ & USD 16.24 & $\begin{array}{l}\text { USD } 51.47- \\
\text { USD } 54.22\end{array}$ & USD 18.74 & $\begin{array}{l}\text { USD } \\
20.14\end{array}$ & $\begin{array}{l}\text { USD } \\
20.14\end{array}$ \\
\hline
\end{tabular}

At 2010, 1\$: PhP40.023

${ }^{\wedge}$ Commercial Building includes apartment stores, restaurant, carenderia/eatery, sari-sari stores, dress/tailoring shops, KTV bar and hard wares.

\subsubsection{Estimated Replacement Costs for Residential Structures}

Table 11 presents the total households affected in the project, residential valuation at various perspectives, estimated replacement cost of respective floor area and total estimated replacement cost per typology. There 175 informal settlers living on the project site, of these 117 are settled in a mixed but predominantly strong materials, 37 settlers are living in a house classified as mixed but predominantly salvaged materials, and 21 residents are living in houses made of makeshift materials. Given the replacement cost in table 8, the sixth column enumerates the estimated replacement cost per land area for each typology. From the area survey conducted by the researchers, the average floor area for residential structures made of salvaged/makeshift and mixed but predominantly salvaged materials is around 24 square meters while mixed but predominantly strong materials is 32 square meters. The last column computes the total estimated replacement cost of the affected households per typology amounting to USD 1,496,352.48. As noticed, bigger bulk of the total estimated replacement cost is attributed to structures which use strong housing materials. In the perspective of the Philippine government, the replacements cost for structures made of salvaged and makeshift material is zero.

Table 11. Replacement Cost for Residential Structure

\begin{tabular}{|l|c|c|c|c|c|c|}
\hline Types of Residential Structure & $\begin{array}{c}\text { Total } \\
\text { House } \\
\text { holds } \\
\text { affected }\end{array}$ & $\begin{array}{c}\text { Commercial } \\
\text { Developer's } \\
\text { Perspective } \\
\text { (sqm) }\end{array}$ & $\begin{array}{c}\text { City } \\
\text { Assessor's } \\
\text { Market Value } \\
(\text { sqm) }\end{array}$ & $\begin{array}{c}\text { Subjective } \\
\text { Value by } \\
\text { Households } \\
(\text { sqm })\end{array}$ & $\begin{array}{c}\text { TEstimated } \\
\text { Replacement Cost } \\
\text { with Respective Floor } \\
\text { Area }\end{array}$ & $\begin{array}{c}\text { Total Estimated } \\
\text { Replacement Cost } \\
\text { per Typology }\end{array}$ \\
\hline Mixed but predominantly strong materials & 117 & 424.76 & $\begin{array}{c}\text { USD 107.6- } \\
\text { USD 112.94 }\end{array}$ & USD 62.46 & USD 12636.48 & USD 1,478,468.16 \\
\hline Salvaged/Make-shift materials & 21 & 124.93 & $\begin{array}{c}\text { USD 46.47- } \\
\text { USD 48.22 }\end{array}$ & USD 12.49 & 0 & 0 \\
\hline Mixed but predominantly salvaged materials & 37 & 174.90 & $\begin{array}{c}\text { USD 51.72- } \\
\text { USD 54.22 }\end{array}$ & USD 16.24 & USD 483.36 & USD 17,884.32 \\
\hline
\end{tabular}

At 2010, 1\$: PhP40.023

个Assumption: The average house size for salvage/makeshift and mixed salvage is both 24 sqm while mixed but predominantly strong is $32 \mathrm{sqm}$.

\subsubsection{Estimated Replacement Costs for Commercial Structures}

Table 12 presents the total commercial structures affected in the project, valuation of commercial structures at various perspective, estimated replacement cost of respective floor area and total estimated replacement cost per typology. In this study, there are 13 affected businesses in the project site. The sixth column calculates the estimated replacement cost per floor area. Based on the area survey, the average commercial structure for salvaged/makeshift and mixed but predominantly salvaged materials is 10 square meters while mixed but predominantly strong materials is 34 square meters. The last column estimates the replacement cost of the commercial structure amounted to USD 95,373.00. The larger share of this figure is apportioned to commercial structure which uses strong materials. 
Table 12. Replacement Cost for ${ }^{\wedge}$ Commercial Structure

\begin{tabular}{|l|c|c|c|c|c|c|}
\hline Types of Commercial Structure & $\begin{array}{c}\text { Total } \\
\text { Businesses } \\
\text { affected }\end{array}$ & $\begin{array}{c}\text { Commercial } \\
\text { Developer's } \\
\text { Perspective } \\
(\mathrm{sqm})\end{array}$ & $\begin{array}{c}\text { City } \\
\text { Assessor's } \\
\text { Market Value } \\
(\mathrm{sqm})\end{array}$ & $\begin{array}{c}\text { Subjective } \\
\text { Value by } \\
\text { Business } \\
(\mathrm{sqm})\end{array}$ & $\begin{array}{c}\text { TEstimated } \\
\text { Replacement Cost } \\
\text { with Respective Floor } \\
\text { Area }\end{array}$ & $\begin{array}{c}\text { Total Estimated } \\
\text { Replacement Cost } \\
\text { per Typology }\end{array}$ \\
\hline Mixed but predominantly strong materials & 10 & 424.76 & $\begin{array}{c}\text { USD 107.44 - } \\
\text { USD 113.18 }\end{array}$ & USD 107.06 & USD 9476.88 & USD $94,768.80$ \\
\hline Salvaged/Make-shift materials & 124.93 & $\begin{array}{c}\text { USD 46.47- } \\
\text { USD 48.72 }\end{array}$ & USD 14.99 & 0 & 0 \\
\hline Mixed but predominantly salvaged materials & 3 & 174.90 & $\begin{array}{c}\text { USD 51.47 - } \\
\text { USD 54.22 }\end{array}$ & USD 18.74 & USD 201.4 & USD 604.20 \\
\hline
\end{tabular}

At 2010, 1\$: PhP40.023

${ }^{\wedge}$ Commercial Building includes apartment stores, restaurant, carenderia/eatery, sari-sari stores, dress/tailoring shops, KTV bar and hard wares.

个Assumption: The average floor size for salvage/makeshift and mixed salvage is both 10 sqm while mixed but predominantly strong is 24 sqm.

\subsubsection{Estimated Replacement Costs for Trees and Other Crops}

Households in the project site grow 2-3 fruit bearing trees on the average. In this study, the most common fruit bearing trees and perennial plant are calamondin (local name: calamansi), guava and coconut tree. The market value of these fruits and perennial plant is shown in Table 13. In this study, 60 percent of the settlers grow these trees and perennial plant. Except for coconut, trees bear fruits twice a year. Thus, the total estimated replacement cost for fruit bearing trees and plant is USD 2,153.89.

Table 13. Market Value of Perennial Plants and Fruit-Bearing Trees

\begin{tabular}{|l|c|}
\hline Kinds & Market Value \\
\hline Coconut/Tree & USD 4.52 \\
\hline$\perp$ (Calamondin)/Tree & USD 5.75 \\
\hline$\perp$ Guava (Native)/ tree & USD 2.25 \\
\hline
\end{tabular}

At 2010, 1\$: PhP40.023; $\perp$ Bears fruits twice a year

\subsubsection{Resettlement of Informal Settlers as Project Affected Households}

Another scheme to compensate for the PAHs is to relocate them to a resettlement area. In case of the Butuan Drainage Project, this option was adopted by the government.

\subsubsection{Philippine Legal Framework for Resettlement of PAHs Affected by Public Projects}

This section discusses The Philippine Republic Act 7279 and Land Acquisition, Resettlement, Rehabilitation and Indigenous People's Policy 2007 (LARRIPP). The former is the foundation of resettlement policy in the Philippines while the latter is the policy and guidelines of Department of Public Works and Highways (DPWH) on resettlement as expressed in the Infrastructure Right of Way Procedural Manual (2003).

\subsubsection{Republic Act 7279 (Urban Development and Housing Act of 1992)}

As stated in Section 28 of the Act, eviction and demolition as a practice shall be discouraged and may be allowed when persons or entities occupy danger areas and when government infrastructure projects with available funding are about to be implemented or when there is a court order for eviction and demolition.

Based on Section 29 of the Act, the local government unit, in coordination with the National Housing Authority, shall provide relocation or resettlement sites with basic services and facilities and access to employment and livelihood opportunities sufficient to meet the basic needs of the affected households. 


\subsubsection{Land Acquisition, Resettlement, Rehabilitation and Indigenous People's Policy 2007 (LARRIPP): DPWH Policy and Guidelines on Resettlement}

The following section is an adoption from the policy and guidelines of ${ }^{1} \mathrm{DPWH}$ on resettlement as expressed in the Infrastructure Right of Way Procedural Manual (2003) and the Land Acquisition, Resettlement, Rehabilitation and Indigenous People's Policy ( $3^{\text {rd }}$ edition in April 2007).

Compensation in LARRIPP shall only be given to legal landowners, owners of structures who have full title, tax declaration, or who are covered by customary law (e.g. possessory rights, usufruct, etc.) or other acceptable proof of ownership, owners of structures, including shanty dwellers, who have no land title or tax declaration or other acceptable proof of ownership, and renters.

\subsubsection{Indicators of Severity of Impacts}

Properties to be acquired for the project may include the entire area or a portion of it. Hence, compensation for such assets or properties depends on whether the entire property will be affected or just a portion of it. The condition is classified as "Severe" if the portion of the property to be affected is more than $20 \%$ of the total land area or even less than $20 \%$ if the remaining portion is no longer economically viable or it will no longer function as intended. The owner of this property (land or structures, etc.) shall be entitled to full compensation in accordance to RA 8974. On the other hand "Marginal" will be the classification if the impact is only partial and the remaining portion of the property or asset is still viable for continued use. Compensation will be on the affected portion only.

\subsubsection{Compensation per Category of Assets Affected}

The classifications or categories of assets to be compensated include land, structures, other improvements, crops, trees and perennials. Compensation for structures will be provided in cash for the affected portion of the structure, including the cost of restoring the remaining structure, as determined by the concerned Appraisal Committee, with no deduction for salvaged building materials. In addition compensation for other improvements will be given as cash at replacement cost for the affected portion of public structures to government or non-government agencies or to the community in case of a donated structure by agencies that constructed the structure. This will also include compensation to cover the cost of reconnecting the facilities, such as water, power and telephone. Lastly, cash compensation for crops, trees and perennials of commercial value will be determined by the DENR or the concerned Appraisal Committee.

\subsubsection{Other Types of Assistance or Entitlements}

Six other types of assistance will be given to PAHs. First is the disturbance compensation for agricultural land severely affected the lessees are entitled to disturbance compensation equivalent to five times the average of the gross harvest for the past 3 years but not less than PhP 15,000 (USD 374.78). Second, coverage for income loss, the PAHs will be entitled to an income rehabilitation assistance to be based on the latest copy of the PAHs' Tax record for the period corresponding to the stoppage of business activities, otherwise not to exceed PhP 15,000 (USD 374.78) for severely affected structures. Third, inconvenience allowance in the amount of $P 10,000$ (USD 249.56) shall be given to PAHs with severely affected structures, which require relocation and new construction. Fourth, rehabilitation assistance in the form of skills training and other development activities equivalent to P 15,000 (USD 374.78)per family per municipality will be provided in coordination with other government agencies, if the present means of livelihood is no longer viable and the PAHs will have to engage in a new income activity. Fifth, rental subsidy will be given to PAHs without sufficient additional land to allow the reconstruction. Lastly, transportation allowance will be given for relocated PAHs.

\subsubsection{Legal Entitlement}

This section specifies the additional entitlements that will be received by the informal settlers affected in the proposed

1 Department of Public Works and Highways, 2011. Resettlement Action Plan in Accordance with the JICA Resettlement Guidelines/Policies for Social Considerations p. 25 
flood mitigation project. The compensations/entitlement is either based from RA 7279 and adoption from DPWH project; and the researchers' recommendation. The entitlement matrix for compensation is shown in Table 14.

Table 14. Matrix for Entitlement Compensation

\begin{tabular}{|c|c|c|c|}
\hline \multirow[b]{2}{*}{ Type of Loss } & \multirow[b]{2}{*}{ Structure Typology } & \multicolumn{2}{|l|}{ Compensation/Entitlement } \\
\hline & & $\begin{array}{l}\text { Under RA } 7279 \text { and adoption from DPWH project (see } \\
\text { note } 3 \text { ). }\end{array}$ & $\begin{array}{l}\text { Researchers' } \\
\text { recommendation }\end{array}$ \\
\hline \multirow[t]{3}{*}{ Structure } & $\begin{array}{c}\text { Mixed but } \\
\text { predominantly } \\
\text { strong materials } \\
\end{array}$ & \multirow{3}{*}{$\begin{array}{l}\text { - Inconvenience allowance P 10,000 (USD 249.86). } \\
\text { - For transportation assistance, microbuses will be } \\
\text { used for free transportation of families that include } \\
\text { children, women and senior people, instead of } \\
\text { trucks. } \\
\text { - For the families with persons who need special } \\
\text { physical or medical care, DPWH } \\
\text { - } \text { will request respective LGUs to provide } \\
\text { - nurses or social workers to help them } \\
\text { - } \text { before and during the resettlement activities. }\end{array}$} & \multirow{3}{*}{$\begin{array}{l}\text { - Cash compensation for } \\
\text { entire structure } \\
\text { (residential and } \\
\text { commercial) at full } \\
\text { replacement cost }\end{array}$} \\
\hline & $\begin{array}{c}\text { Salvaged/Make-shift } \\
\text { materials }\end{array}$ & & \\
\hline & $\begin{array}{c}\text { Mixed but } \\
\text { predominantly } \\
\text { salvaged materials }\end{array}$ & & \\
\hline $\begin{array}{l}\text { Crops, Trees, } \\
\text { Perennials }\end{array}$ & & $\begin{array}{l}\text { - Cash compensation for crops (which are not yet } \\
\text { suitable for harvesting), trees, and perennials at } \\
\text { current market value as prescribed by the } \\
\text { concerned LGUs and DENR, confirmed by DPWH } \\
\text { as the same level with market value. }\end{array}$ & $\begin{array}{l}\text { - Cash compensation for } \\
\text { crops, trees and plants } \\
\text { at market value. }\end{array}$ \\
\hline $\begin{array}{l}\text { Improvements } \\
\text { (pig pen, dog houses, } \\
\text { pigeon houses, fences) }\end{array}$ & & $\begin{array}{l}\text { - Cash compensation for the affected improvement } \\
\text { at full replacement cost. }\end{array}$ & $\begin{array}{ll}\text { - } & \text { Cash compensation for } \\
\text { entire structure at full } \\
\text { replacement cost }\end{array}$ \\
\hline \begin{tabular}{|l|} 
Livelihood \\
Rehabilitation \\
Assistance/Training
\end{tabular} & & $\begin{array}{l}\text { DPWH will monitor the change of living standard of } \\
\text { the PAF before and after the resettlement. } \\
\text { - When the PAF are found that their living standard } \\
\text { worsen, or whose present means of livelihood } \\
\text { became not-viable, DPWH, in coordination with } \\
\text { other appropriate institutions, will provide } \\
\text { assistances, such as skills and livelihood trainings. }\end{array}$ & \\
\hline
\end{tabular}

\subsubsection{Total Resettlement Cost for the Project Affected Households}

Following all the legal provisions for resettlement, Table 15 shows the estimated cost for 175 project affected households. The total amount is estimated at USD 14,147,765.26. This excludes the cost estimation for internal and external monitoring and evaluation; and price escalation and taxes. The account name, Development of relocation site includes the cost on house and lot, road, water supply, electricity and site development.

Table 15. Total Estimated Resettlement Cost

\begin{tabular}{|l|c|c|}
\hline Activities & $\begin{array}{c}\text { Estimated Cost } \\
\text { (PhP) }\end{array}$ & $\begin{array}{c}\text { Estimated Cost } \\
\text { (USD) }\end{array}$ \\
\hline A. Preparatory Services & $2,250,000$ & $56,217.67$ \\
\hline B. Capability Building, Skills and Livelihood Training Programs for Project & $36,000,000$ & $899,482.80$ \\
Affected Families & & \\
\hline C. Acquisition of Properties & $396,000,000$ & $9,894,310.77$ \\
Land acquisition including payments of various & $10,500,000$ & $262,349.15$ \\
Subdivision Survey, Parcellary Survey and Relocation Survey of affected lots & $3,750,000$ & $93,696.12$ \\
including access road and Relocation Site & & \\
Miscellaneous Expenses (Expropriation, Barter and related activities & $6,670,800$ & $166,674.16$ \\
\hline D. Transfer and Titling of Properties & $7,872,000$ & $196,686.91$ \\
Taxes and fees & $3,000,000$ & $74,956.90$ \\
Titling expenses & \\
Other expenses including legal advisory fee & \\
\hline
\end{tabular}




\begin{tabular}{|l|c|c|}
\hline E. Clearing of Structures, Improvements and Removal of Dwellers & $26,340,000$ & $658,121.58$ \\
\hline F. Administrative Expenses & $21,600,000$ & $539,689.68$ \\
Butuan Local Government Units (Local Project Management Team) & $10,500,000$ & $262,349.15$ \\
Purchase of Vehicular Service & $32,986,009$ & $824,176.32$ \\
\hline G. Development of Relocation Site & $8,767,200$ & $219,054.04$ \\
\hline H. Contingency Reserve & $566,236,009$ & $14,147,765.26$ \\
\hline TOTAL & & \\
\hline
\end{tabular}

\subsubsection{Total Costs of Compensating the Informal Settlers as Project Affected Households}

Overall, to ensure the equitable compensation for the displaced informal settlers, the informal settlers' upgrading costs would incur the government an estimated amount of PhP 629,287,876.99 or USD 15, 723, 156.11.

Table 16: Total Estimated Cost of Compensating Informal Settlers

\begin{tabular}{|l|c|c|}
\hline Activities & Estimated Cost (PhP) & Estimated Cost (USD) \\
\hline Total Replacement Cost Physical Structures (Residential) & $59,172,731.17$ & $1,478,468.16$ \\
\hline Total Replacement Cost Physical Structures (Commercial) & $3,792,931.68$ & $94,768.80$ \\
\hline Total Replacement Cost Crops and Trees & $566,236,009$ & $14,147,765.26$ \\
\hline Total & $629,287,876.99$ & $15,723,156.11$ \\
\hline
\end{tabular}

\subsubsection{Financing the Compensation Cost for the Informal Settlers}

The local government intends to request a loan from the Asian Development Bank (ADB) to finance the project. The loan will have a term of 25 years, including a grace period of 6 years, with an interest charge at the rate of $1.07 \%$ (comprising $0.87 \%$ 5-year Japanese Yen swap rate and 0.20\% ADB spread) per annum. The ADB loan proceeds will be on-lent to the Government of the Philippines and to each participating local government unit and water district. The Government of the Philippines will bear the foreign exchange risk. Interest during the project implementation period will be capitalized. The ADB loan will finance $79.7 \%$ of the project cost, and co-financing through the Global Environmental Facility will finance $2.4 \%$. About $18 \%$ of the total project cost will be provided by the Government of the Philippines though DENR (ADB, 2011).

\section{Conclusion}

With the implementation of the flood mitigation project through the Butuan City Drainage Project, a number of the city's residents particularly informal settlers in the project site were directly affected, hence the need to be compensated or relocated to appropriate resettlement sites. This paper has two purposes. First, the paper seeks to broaden the inquiry into the modalities of compensating justly informal settlers affected by a government through upgrading initiative. Secondly, it tries to incorporate the estimation of the cost such modalities will incur. This comprehensive review is intended to provide a solid baseline of information on experience of in upgrading in Philippines.

Economically speaking, if the government is forced to pay for what it acquires, it should strive to make rational economic decisions that will bring beneficial development to all parties. In the spirit of social justice, the government has to give protection to the reasonable expectations of those who will be affected and relied on it, particularly the marginalized, as in the case of the informal settlers. Just solutions must not only consider the replacement cost but also the resettlement cost for the affected households and their livelihoods. It must ensure that the living standards and future livelihoods are maintained and improved. It should not hamper the informal settlers' previous access to social, economic and political activity.

The findings of the study have crucial policy implications which should increase policymakers' awareness that informal settlement represent a solution well as cause a great burden. In the case of the Butuan Drainage project, the compensation for the informal settlers resulting from the project may be a means to uplift the economic conditions of these members of society and improve their economic well-being. However, informal settlers add up to the financial burden of implementing public infrastructure projects. The compensation measures add to the cost of implementing public infrastructure projects. This evident in the Butuan Drainage Project where a substantial amount was needed to implement 
the project. Governments reap great public costs from the resulting informal settlements mid and long-term. The costs could divert valuable government resources into expenditures which otherwise could have been spent on other development projects. Thus it is imperative that local government units must be effective in preventing unguided land invasions as well as establish sustainable solutions that address the problems causing informal settlements.

\section{References}

Acquired Properties for Sale. Green Bank of Caraga. www.greenbank.com.ph

Asian Development Bank. (2011). Agusan River Basin Integrated Water Resources Management Project. Draft Final Report. Vol. 1.

Baken, J.-R. (2003). Plotting, Squatting, Public Purpose and Politics. University of London: Ashgate, 9 - 22.

Botes, L. \& Rensburg, D.V. (2000). Community Participation in Development: Nine Plagues and Twelve Commandments. Community Development Journal, 35, 41-58.

Cohen, M., (2001). Urban Assistance and the Material World: Learning by Doing at the World Bank. Environment and Urbanization 13 (1), 37-60.

de Soto, H., (2000). The Mystery of Capital: Why Capitalism Triumphs in the West and Fails Everywhere Else. New York, Bantam Books.

Eckert, Joseph, ed. (1990). Property Appraisal and Assessment Administration. 231.

Economic Commission for Europe (ECE). (2004). Conference Vienna. Expropriation, Compensation, and Valuation: ADB Policy and International Experience. www.adb.org/Documents/...Compensation-Valuation/chap1.pdf

Ferguson, Bruce. (1996). The environment impacts and public costs of unguided informal settlement; the case of Montego Bay. Environment and Urbanization. <http://eau.sagepub.com/content/8/2/171>

Gabriel, B. (2007). "Informal Settlements in SEE - A regional support approach Spatial Information Management toward Legalizing Informal Urban Development". Paper presented at "Informal Settlements - Real Estate Markets Needs Related to Good Land Administration and Planning" FIG Commission 3 Workshop, Athens, Greece, March 28-31, 2007

Keare, D. H. and S. Parris. (1982). Evaluation of Shelter Programs for the Urban Poor: Principle Findings. Washington, DC, The World Bank.

Knetsch, Jack L., and Thomas E. Borcherding. (1979). Expropriation of Private Property and the Basis for Compensation. University of Toronto Law Journal, 29(237).

Magalhaes, Fernanda; Rojas, Eduardo. (2005). The re-urbanization of the city center of Manaus, Brazil - Facing the challenges of informal settlements. 41st ISoCaRP Congress 2005.

Mehta, M. and D. Mehta., (1990). Home Upgradation and Income Generation from Housing. In: The Place of Home-based Enterprises in the Informal Sector: Evidence from Cochabamba, New Delhi, Surabaya and Pretoria Urban Studies April 2005 42: 611-632. http://usj.sagepub.com/content/42/4/611.refs

Mitlin, Diana, \& Satterthwaite, D. (2004). Empowering Squatter Citizen: Local Government, Civil Society and Urban Poverty Reduction. London: Earthscan.

Participatory Agricultural Development and Empowerment Project (PADEP). Ministry of Agriculture and Food Security in Tanzania. (2003). http://www.agriculture.go.tz/publications/english\%20docs/Tanzania\%20PADEP\%20EI\%20Report.pdf

PRC Thematic Report No. 2: Asset Valuation in Land Acquisition and Compensation. www.adb.org/Documents/Reports/Capacity...PRCThematic/Report2.pdf

Properties for Sale. Rizal Commercial Bank Corporation. www.rcbc.com/prop.php

Properties for Sale. Metrobank. http://www.metrobank.com.ph/assets_for_sale.asp

Properties for Sale. Allied Bank. http://www.alliedbank.com.ph/properties_for_sale.php

Tsenkova, Sasha et al. (2008). In Search for Sustainable Solutions for Informal Settlements in the ECE Region: Challenges and Policy Responses. Economic Commission for Europe. Committee on Housing and Lang Management

UN Habitat. (2003). Slums of the World: The Face of Urban Poverty in the New Millennium? Working Paper, United Nations Human Settlements Programme (UN-HABITAT). http://www.unhabitat.org/pmss/listltemDetails.aspx?publicationID=1124

UN Habitat. (2010). The Challenge of Slums: Global Report on Human Settlements 2003 (Revised April 2010). http://www.unhabitat. org/downloads/docs/GRHS_2003_Chapter_01_Revised_2010.pdf

Weldegebriel, Daniel. Land Valuation for Expropriation in Ethiopia: Valuation Methods and Adequacy of Compensation, $7^{\text {th }}$ FIG Regional Conference, Hanoi Vietnam, 19-22 October 2009. www.fig.net/pub/vietnam/ papers/ts04c/ts04c_ambaye_3753.pdf

World Bank. (2003). Informal Settlement Upgrading in Sub-Saharan Africa: Retrospective and Lessons Learned. http://people.virginia.edu/ emb7d/docs/wblitreview-Jan03_web.pdf

\section{Government Documents}

Assessment for Crops/Plant and Trees. City Agriculture Office, Butuan City Hall, CARAGA Region

Barangay Development Plan. City Planning and Development Office, Butuan City Hall, CARAGA Region

Land and Structure Assessment for Butuan Land and Structure. City Assessor Office, Butuan City Hall , CARAGA Region

Low Cost Housing Price Schedule. City Housing Office, Butuan City Hall, CARAGA Region 
Negotiated Sale Properties. Land Bank of the Philippines, Montilla Blvd. Butuan City, CARAGA Region

Philippine Country Paper presented during the ADBI-OECD Conference on Skills Development in the Post-Crisis Context, 28-30 September 2010, Tokyo, Japan 